TECHNICAL NOTES AND MANUALS

\title{
Modernizing Cash Management
}

Ian Lienert

Fiscal Affairs Department

I NTERNATIONAL MONETARY FUND 


\section{INTERNATIONAL MONETARY FUND}

Fiscal Affairs Department

\section{Modernizing Cash Management}

Prepared by lan Lienert

Authorized for distribution by Carlo Cottarelli

October 2009

DISCLAIMER: This Technical Guidance Note should not be reported as representing the views of the IMF. The views expressed in this Note are those of the author and do not necessarily represent those of the IMF or IMF policy.

\begin{tabular}{|l|l|}
\hline JEL Classification Numbers: & H61, H62, H63, H68 \\
\hline Keywords: & government cash management, cash planning, reforms \\
\hline Author's E-mail Address: & ilienert@imf.org \\
\hline
\end{tabular}




\section{TECHNICAL NOTES AND MANUALS}

\section{Modernizing Cash Management}

\section{Prepared by lan Lienert}

The five sections of this note ${ }^{1}$ address the following main issues:

- What are the main objectives of modern cash management?

- What are good cash management practices in developed countries?

- What are the main features of the framework for short-term cash planning?

- What are the main challenges for improving cash management in low- and middle-income countries?

- How should cash management reforms be sequenced?

\section{Definitions and Objectives of Cash Management}

Cash has been defined in the Government Financial Statistics (GFS) manual. ${ }^{2}$ In GFS, cash on hand refers to notes, coins, and deposits held on demand by government institutional units with a bank or another financial institution. Cash equivalents are defined to be highly liquid investments that are readily convertible to cash on hand. A major focus of this paper is on managing government "cash on hand." However, as will be seen in the discussion on active cash management, Treasuries are also concerned about managing "cash equivalents."

Cash management is necessary because there are mismatches between the timing of payments and the availability of cash. Even if the annual budget is balanced, with realistic revenue and expenditure estimates, in-year budget execution will not be smooth, since both the timing and seasonality of cash inflows (which depend in turn on tax and nontax flows, and timing of grant or loan disbursements) and of expenditures can result in conditions of temporary cash surpluses or temporary cash shortfalls. For example, if taxes are paid quarterly, there can be large

\footnotetext{
${ }^{1}$ An earlier version of this note was previously issued as part of a series of technical notes on the IMF's Public Financial Managment Blog (http://blog-pfm.imf.org). This note has benefited from peer review by B. Olden, G. Ljungman and H. van Eden, helpful comments from other FAD/IMF colleagues, including R. Allen, D. Bouley, I. Fainboim, M. Lazare, and M. Pessoa, as well as very valuable comments by M. Williams, IMF consultant.
}

${ }^{2}$ See paragraph 4.47 of the GFS Manual, IMF, 2001. 
temporary cash surpluses around the time taxes are due, and temporary deficits in other time periods.

All definitions of cash management emphasize the time value of government money. Storkey (2003) provides the following definition: "cash management is having the right amount of money in the right place and time to meet the government's obligations in the most cost-effective way." Other definitions emphasize active cash management of temporary cash surpluses and temporary deficits. $^{3}$

\title{
Modern cash management has four major objectives:
}

- To ensure that adequate cash is available to pay for expenditures when they are due. Pooling revenues in a treasury single account (TSA) facilitates this.

- To borrow only when needed and to minimize government borrowing costs.

- To maximize returns on idle cash, i.e., to avoid the accumulation of unremunerated or lowyielding government deposits in the central bank or in commercial banks.

- To manage risks, by investing temporary surpluses productively, against adequate collateral.

Effective cash management contributes to the smooth implementation of the operational targets of fiscal policy, the public debt management strategy, and monetary policy.

\section{Key Features of Modern Cash Management}

\begin{abstract}
At least nine important features can be identified for effective modern cash management in advanced countries. Six fundamental features and three other desirable features have been identified in Box 1. All nine features are practiced in advanced OECD countries.
\end{abstract}

\section{Discussion of selected fundamental features of effective cash management}

\section{The centralization of government cash balances-establishing a TSA system ${ }^{4}$-is} particularly important. In most advanced countries, nearly all revenues are consolidated daily in a TSA, which is firmly under the control of the Treasury of the Ministry of Finance (MoF). ${ }^{5}$ Through the TSA, the MoF has full access to all cash resources held in the central government ministries and agencies at any given time. The main bank account of the TSA system of accounts is held at the central bank and is used for receiving all government revenues and

\footnotetext{
${ }^{3}$ Williams (2004) defines cash management as "the strategy and associated processes for managing cost-effectively the government's short-term cash flows and cash balances, both within government, and between government and other sectors." In France, active cash management consists in investing temporary surplus cash in the account at the highest yield and safety while maintaining a credit balance in the account. See Agence France Trésor-AFT, 2007.

4 The establishment of a TSA is discussed more fully in Fainboim, Israel and Pattanayak, Sailendra. 2009, Treasury Single Account: Concept, Design, and Implementation Issues, IMF Working Paper, forthcoming.

${ }^{5}$ In this paper "Ministry of Finance" and "the Treasury" are used generically; the latter indicates the department within a MoF that is responsible for centralized cash management and also for debt management, even if carried out be a separate unit that has some degree of autonomy (institutional arrangements differ across countries).
} 
making government payments. When establishing a TSA, the government payment function can be centralized (e.g., France, Germany, and the United States)—with all disbursements made directly from the main operational account of the TSA at the central bank (with few exceptions). Alternatively, payments can be decentralized, and made by spending ministries from accounts held in commercial banks. ${ }^{6}$ Each day, the balances in ministries' bank accounts are swept into the TSA and the government's cash manager ensures that only a minimum end-of-day balance remains in the TSA's main account at the central bank. Temporary cash surpluses are usually remunerated by the central bank or placed in financial market instruments (this is discussed more fully below).

\section{Box 1. Nine Features of Modern Cash Management}

\section{Fundamental features}

- Centralization of government cash balances and establishment of a TSA structure

- Clear understandings on the coverage of the cash planning framework

- Ability of make accurate projections of short-term cash inflows and outflows

- An adequate transaction processing and accounting framework

- Timely information sharing between the central treasury, revenue-collecting agencies, spending ministries, and/or treasury branch offices

- Appropriate institutional arrangements and responsibilities

\section{Desirable features}

- Utilization of modern banking, payment, and settlement systems

- Use of short-term financial market instruments for cash management

- Integration of debt and cash management

The coverage of the cash management framework is clearly defined. The overall macrofiscal framework for "general government" (GFS definition) often incorporates revenues and expenditures that are not included in the central government's annual budget. In OECD countries, for example, extrabudgetary funds for social security are commonplace. In some advanced countries, the coverage of funds available for active cash management is considerably larger than the central government budget. ${ }^{7}$ In low-income countries (LICs), some expenditures financed by donor grants or multilateral loans may be excluded from the annual budget adopted by the parliament of the recipient country. Even if donor funds are included in the annual budget

\footnotetext{
${ }^{6}$ For example, in Australia, spending agencies are not only responsible for spending authorization and internal control, but also for internal cash management. Although financial transactions are made from agencies' bank accounts, all end-of-day balances are swept into the TSA at the Reserve Bank of Australia. In effect, there is a two-tier cash management system: one at the level of spending agencies, and a consolidated cash management system at the federal level.

${ }^{7}$ France is perhaps the most extreme example: the Cash and Debt Management Agency (Agence France Trésor) manages not only the central government's cash balances, but also those of all local governments and a number of other public entities. In federal countries, due mainly to the independence of subnational levels of government, but also because of the complexity of forecasting daily cash requirements of agencies at all levels of government, the treasury's cash management activities are limited to the cash flows associated with the central government's budget.
} 
framework, cash available for financing the associated expenditures is often held in special accounts, separate from the government's TSA held at the central bank. More generally, for effective pooling of government cash, it is desirable that the Treasury be able to tap into the cash balances of extrabudgetary funds. Thus, the coverage of the funds available for cash management needs to be clearly defined.

Short-term cash planning and projections. Effective cash management can only take place if there are skills and capacity to record, monitor, and project short-term inflows and outflows into the TSA. A framework for short-term cash planning is discussed in section III.

\section{Adequate transaction processing, accounting frameworks, institutional arrangements, and} information sharing. In order to make short-term projections, cash managers need to have adequate historical data for projecting all inflows and outflows from the TSA (revenue remittances, payments for expenditures, debt transactions, etc.). In advanced countries, high-quality, timely, and comprehensive data on government cash transactions are usually readily available in the government's accounting system, which is fully computerized. For short-term cash projections, relevant players contribute to the provision of necessary data. Information sharing networks have been set up, and there are clear understandings of the responsibilities of each government entity for different aspects of cash management.

\section{Realistic budget projections and/or conservative revenue projections are helpful for} avoiding cash management problems. Some advanced countries deliberately underestimate economic growth and projected budget revenues. ${ }^{8}$ Although this has been done primarily for fiscal prudence- the avoidance or reduction of excessive fiscal deficits—-such practices have a favorable impact on cash management, especially in countries that have limited, or no, access to short-term financial markets. When revenues fall short of conservative budget projections, there is less need to tighten expenditure controls, which is used as a cash management instrument in LICs.

\section{Good Practices for Managing Daily Cash Balances}

\section{Advanced countries attach high importance to the opportunity cost of holding idle cash.}

Holding banknotes or government cash in unremunerated bank accounts is particularly costly. Placing temporary cash surpluses in low-yielding instruments also imposes a financial cost on the government. Similarly, revenue float, i.e., delays in transmitting revenue from government accounts in commercial banks to the TSA, is inefficient. In some countries several days elapse before revenues reach the TSA; this is a hidden government subsidy to commercial banks. ${ }^{9}$ Similarly, float in government expenditure accounts—-the provision of money from the TSA to a

\footnotetext{
${ }^{8}$ An analysis of budget forecasts in 11 OECD countries indicated that several of them (and Canada in particular), prepare deliberately conservative revenue projections. See chapter IV of IMF, 2007.

${ }^{9}$ Commercial banks in several Latin American countries are not explicitly "remunerated" for providing services to Treasuries. Instead, they benefit from the long delays in transmitting taxpayers' revenues from deposits in the banks to the government's TSA. Examples are: 3 days in Ecuador, Mexico, and Peru; and 15 days in Colombia.
} 
"transit" account prior to the day on which disbursement takes place-also provides an implicit subsidy to a commercial bank (or to the central bank when the government makes payments from its central bank account). Ultimately, the taxpayer bears the opportunity cost of bank float and unremunerated government deposits. In recognition of the time value of government money, modern cash managers have adopted the practices described in Box 2.

\section{Box 2. Recognizing the Time Value of Cash Used by Government}

- Government cash resources are pooled in a TSA.

- Idle balances are minimized, thereby avoiding unnecessary government borrowing. Unremunerated government deposits in the banking system are avoided.

- Revenue and expenditure float nonexistent. All non-TSA government bank accounts have zero balances at the end of each working day.

- Transactions are conducted through the banking system. Electronic transactions are maximized, so as to reduce transactions delays, and increasingly, to replace checks processed in payment clearing systems. These practices contrast with those used in countries with inefficient payment systems and underdeveloped banking systems, which may even involved the transportation of physical cash (banknotes).

- Banks providing treasury services are remunerated on a per transaction basis, independent of the value of the transactions. Qualified banks are selected by competitive bidding for providing revenue transmittal services and/or making payments on behalf of government. Banks' ability to sweep balances back to the TSA, reducing idle balances to zero, is highly relevant.

- Payments are made in real time. Disbursement (payment) delays and penalties for late payment are thereby avoided.

- Targets for end-day TSA balances are usually adopted..$^{10}$ Any unexpected cash calls (e.g., due to timing differences) can be financed through short-term borrowings in the government securities market or by the banking system, so as to minimize the need to hold large low-yielding cash balances.

- Temporary surpluses in the TSA are invested in interest-bearing instruments, usually with full collateral so as to minimize risk. There is increasing participation of treasuries in secondary markets for government securities, with the twin objectives of maximizing returns on available balances and avoiding timing mismatches.

Taking advantage of modern banking systems and financial instruments. Good cash management is facilitated when all government transactions take place through modern banking systems, that is, one in which commercial banks are networked electronically with their own branches, and where the interbank settlement system is well established and integrated with the central bank's payment system, via real time gross settlement (RTGS) systems. Modern treasuries

\footnotetext{
${ }^{10}$ For example, end-day balances in France, the United Kingdom, and the United States are respectively 100 million Euro, 200 million pounds approximately (as it varies from week to week), and US\$5-7 billion.
} 
avail themselves to such tools and use electronic revenue transmission and payment methods. In advanced countries, when there are temporary cash shortages or surpluses, the government's cash manager, who is monitoring the consolidated balances of all government accounts on a daily basis, borrows or lends to the financial markets. In EU countries, for example, treasuries are often active in repo markets. ${ }^{11}$ When treasuries are active market participants, there is a beneficial impact on money market development.

Introducing appropriate institutional arrangements and clear responsibilities. In advanced countries, there are clear understandings between the MoF's cash managers and other entities, especially the central bank and commercial banks, as to their respective roles in cash management and debt management. As the central manager of government cash, the MoF takes the lead in negotiating protocols of understanding that lay out: (1) the roles that the MoF may delegate to commercial banks and/or the central bank, for example, electronic revenue collections or payments of various government expenditures (foreign currency payments are usually made by central banks, since foreign exchange market considerations are at stake); (2) the remuneration that commercial banks and the central bank receive from the government for performing treasury banking services; (3) the obligatory exchanges of data and information between government bodies; and (4) the basis of the interest paid by the banks or central banks to the treasury. Within the MoF itself, there is also a need for frequent exchanges between the budget, treasury, and debt departments with regard to cash management issues. All of these functions require staff with appropriate technical abilities. Clear regulations for cash management arrangements are also needed.

Coordinating cash managers, debt managers, and monetary authorities. Cash managers need to collaborate with those responsible for debt management, especially when cash management and debt management are conducted in separate units within the MoF. Since active cash managers' focus is very short term, there is a need to collaborate with government debt managers whose outlook is somewhat more long term, and with the monetary authorities (central bank). In this context, the following considerations are important:

- Government cash management and debt management objectives may potentially conflict. Whereas a major preoccupation of cash managers in advanced countries is to maximize returns on idle cash balances and minimize borrowing costs on a daily basis, government debt managers are concerned that government borrowing plans be orderly. Cash managers participate actively in financial markets-placing temporarily idle cash balances for short durations or borrowing for short-time periods. Modern debt managers pre-announce regular schedules of government borrowing, consistent with annual debt management operational

\footnotetext{
${ }^{11}$ A repurchase agreement (repo) is an instrument by which the MoF obtains cash by selling a security, usually a Treasury bill or government bond. A reverse repo is used by the MoF for placing temporary cash in exchange for the purchase of a security (e.g., treasury bill or bond), with an agreement for the transaction to be reversed at a future date. Repo market activities are fully collateralized. Besides participating in secured markets, the treasuries of a few countries borrow or lend in unsecured markets, but to a very limited extent.
} 
plans. ${ }^{12}$ From a cash manager's perspective, the pre-announced borrowing plans may result in borrowing too much, or too little, thereby thwarting the effectiveness of daily cash management. These apparent conflicts can be resolved by close coordination and exchange of information and intentions between government cash managers and debt managers, which may result in modifications in the volume of treasury bills auctioned.

- Government cash managers and the central bank both need short-term projections of government cash needs. With active cash management, the MoF needs to share, on a daily basis, its updated projections of government cash needs. It is useful for the central bank to compare these projections with its own projections of bank liquidity. Since the net transfer of liquidity between the government and nongovernment sectors is often the largest and most volatile item in central bank liquidity forecasting exercises, projections need to be as accurate as possible.

Moving government deposits from the central bank to commercial banks affects monetary policy implementation. Although a few countries (e.g., France) use only the central bank for government retail banking transactions, most countries use commercial banks. Advanced countries also frequently place large amounts of surplus liquidity in the market, through, for example, reverse repo operations or placing term deposits with commercial banks. Movements of government funds from the central bank to the financial markets (or vice versa) affect bank liquidity and hence market interest rates. Government cash managers, therefore, need to collaborate with the central bank, especially concerning any unanticipated movements of government funds. In the United States, for example, there is a daily conference call between the U.S. Treasury and the Federal Reserve Bank, where proposed movements of federal funds are indicated.

\section{Cash Planning and Projections}

For effective cash management, the treasury needs to develop accurate and timely shortterm estimates of cash inflows and outflows. The flows to be forecast include government receipts and payments (i.e., those that contribute to the fiscal balance-deficit or surplus) and financing transactions (i.e., changes in net financial assets and liabilities, which finance the fiscal balance). A key objective is to anticipate the cash needs of the government and to ensure that payments are made in a timely manner.

\footnotetext{
12 Debt managers undertake borrowing for fiscal deficit financing. Increasingly, they make plans in the context of a comprehensive government asset and liability management framework (Wheeler, 2004) and with regard to a credible bond issuance strategy and prudent risk management (IMF and World Bank, 2001 and 2003).
} 
Key features of a cash forecasting framework. These include the need to:

- Have a comprehensive framework that includes all inflows of government cash resources and provides a framework for planning the payment of short- and long-term cash liabilities when they fall due. This requires budget information management systems that are comprehensive, with data that are timely, accurate, and reliable.

- Align expenditure planning and actual cash spending by line ministries, so that there is no disruption to spending during budget execution, or any payment arrears. This requires ministries to carefully plan expenditures, in collaboration with the MoF, which, in turn, needs to be responsive to the cash needs of line ministries.

- Provide incentives to budget institutions to supply realistic cash plans. There are always uncertainties in making projections: agencies' in-year plans may change; contracts are not signed when expected; invoices are not received as anticipated, etc. However, when moving away from a cash rationing system towards a more active cash management, a carrot and stick approach may be necessary. Budget institutions that submit accurate projections of cash needs can be provided with increased autonomy to manage spending of their budget appropriations. ${ }^{13}$

\section{Forecasting is a technical exercise that requires collaboration with all interested parties.}

Desirable features for the preparation of short-term cash plans are:

- Consistency with annual budget projections. The starting point for in-year cash plans is the cash needed to implement the annual budget adopted by Parliament. The regular updates of projections of daily, weekly and monthly cash flow forecasts continue to be constrained by the projections of the annual budget (on a cash basis).

- Concentrating on the major inflows and outflows. The focus should be on ensuring that the projections for the major taxes and other revenues, and for the most important expenditures, are as realistic as possible. The projections of small revenues and expenditures can be assumed to follow a simple pattern.

- Identifying past patterns for particular inflows and outflows. For this, an information database should be developed, using historical data from the government's financial management system. The cash projection module, although using historical accounting data, can have a separate database. It is timeliness of data and the ability to generate scenarios that are crucial.

- Identifying the timing of the major flows. Some large flows are specific as to timing and can be identified in advance. These may include: tax payments by the largest companies; grants by foreign donors; bond issuances and redemptions; salary payments; interest on government debt; payments on major public projects; transfers to lower levels of government; and social welfare or pension payments.

\footnotetext{
13 This incentive is made explicit in the case of the United Kingdom. Spending ministries with a poor forecasting record have penalties deducted from their following year's expenditure provision, which are recycled to ministries with better forecasting records. The penalties are based on the extra market cost that the cash managers face in having to borrow or lend at short notice as a result of forecasting errors.
} 
- Developing links between the treasury and revenue-collecting agencies for the preferred timing of inflows. When there is a choice concerning the timing of inflows, it is important that the treasury consults with the tax and customs agencies. To balance outflows and inflows, the treasury may suggest to the tax collecting agency that tax payment dates be made in the middle of the month if there is typically a cash outflow in the middle of a month. Similarly, for infrequent sales of capital assets (e.g., receipts from privatization), the treasury would try to ensure that the receipts from the proceeds of the sale are deposited in the TSA on a day that there would otherwise be an outflow.

- Developing contacts between the MoF and ministries at operational level. The treasury needs to obtain information from the agencies that are closest to the transactions. Spending ministries' headquarters should be able to obtain the necessary information from their lower level budgetary units. The MoF's cash management unit can assign staff to liaise with spending agencies on their cash flow projections. Any changes in projections, especially if they are of large value, need to be notified promptly to the cash managers, ${ }^{14}$ to enable them to update aggregate cash flow forecasts. Real time information-sharing is most useful.

- Ascertaining cash needs from expenditure commitments. Ministries and agencies are best placed to project trends in their expenditures (and revenues they collect). It is ministries that enter into contractual arrangements that later require invoices to be paid. Typical delays between the recording of expenditure commitments and the payment of goods or services are known by spending ministries. It is important to ensure that ministries and agencies prepare financial plans: both a schedule of commitments and likely cash outflows. When commitment limits are in place, for example quarterly, the predictability of cash outflows is enhanced.

- Distinguishing information-sharing from expenditure control. Ministries may need to be reassured that the information provided to the treasury will be used only for cash management purposes, not for expenditure control purposes. If this is not clear, ministries may be reluctant to provide unbiased estimates of cash needs or, worse, withhold information, including on revenues that they generate through their own operations and hold in bank accounts outside oversight of the treasury.

The projections of the cash plan need to be regularly updated. Over time, they should also be refined. The broad framework of an initial cash plan, based on monthly projections consistent with the annual budget, is sketched in Table 1. In advanced countries, daily projections of cash flows are prepared for at least three months ahead, and these are rolled forward frequently. In less developed countries, weekly or 10-day projections are often prepared in the first instance. ${ }^{15}$ The largest items are disaggregated, with a view to preparing detailed projections by revenue-collecting

\footnotetext{
${ }^{14}$ In France, for example, the AFT requires local governments to provide advance notice, by 4 p.m. of the previous day, of large-value transactions-those exceeding Euro 1 billion (see AFT, 2006). In the United States, the U.S.

Treasury requires disbursements or collections exceeding $\$ 500$ (or $\$ 50$ ) million to be notified 5 (or 2 ) business days in advance (see Rascoe, 2007).

15 For example, Burkina Faso prepares monthly cash plans, which are approved by a high-level committee, and 10day projections within the monthly cash plans, which are managed by the Treasury Department of the MoF.
} 
agency or by major spending ministry, and also to pin-pointing the exact day in which large revenues are received or large payments made.

The frequency of updating should eventually be daily. As cash management becomes more active, the government cash manager will seek to minimize daily idle cash balances, and may borrow to address short-term temporary shortages of cash. The updating of forward cash plans eventually needs to become daily. For the most advanced countries, within-the-day cash management is practiced.

\section{Modern cash planners offset any temporary cash deficits or cash surpluses, primarily by} market-based short-term borrowing. In the hypothetical example of a balanced budget and back-loaded revenues shown in Table 1, the government cash manager would need to borrow in the early part of the year, so as to avoid the negative net balances projected for seven of the first nine months of the fiscal year (see final line of lower panel of Table 1). In this example (which assumes no bond issuance), all within-the-year borrowings would be repaid by year-end.

\section{In LICs, if there is a cash shortfall, and short-term borrowing is not an option, multiple} measures for resolving the shortfall would need to be considered. These include: accelerating revenue collections; delaying expenditure (preferably at the commitment stage, rather than at the cash stage, as the latter results in payment arrears); and amending the annual budget if the revenue shortfalls are a result of optimistic budget revenue projections.

Cash forecasting unit. The cash management unit needs to assign a few staff to update the technical forecasts. The team of officials is usually quite small (perhaps 3-5 people full-time).

Information technology (IT) needs. The more complex the information, the more there is a need for high-quality information systems. High-performing IT systems are needed to facilitate the preparation and updating of short-term cash projections and the maintaining databases of cash-flow trends. One option is to include a tailor-made cash forecasting module as part of an integrated financial management information system (IFMIS), with the accounting module of the IFMIS would provide data on inflows and outflows. In countries where there is considerable decentralization of financial management to spending agencies, with short-term projections regularly updated by ministries, in their own IT systems, there is a need to ensure that the ministries' projections are communicated to the central cash managers' IFMIS and consolidated. 
TABLE 1. CONSOLIDATED ANNUAL CASH PLAN

Year $=[20 \mathrm{xx}]$ Date of last update $=\mathrm{Time} / \mathrm{D} / \mathrm{M} /$ Year

Currency (millions)

\begin{tabular}{|c|c|c|c|c|c|c|c|c|c|c|c|c|c|c|c|}
\hline \multirow[t]{2}{*}{ Code } & Major Budget Headings & $\begin{array}{l}\text { Approved } \\
\text { Budget }\end{array}$ & Jan & Feb & Mar & Apr & May & June & Jul & Aug & Sep & 0ct & Nov & Dec & Total \\
\hline & & Proj. & $\begin{array}{l}\text { Proj/ } \\
\text { Ac }\end{array}$ & $\begin{array}{l}\text { Proj/ } \\
\text { Ac }\end{array}$ & $\begin{array}{l}\text { Proj/ } \\
\text { Ac }\end{array}$ & $\begin{array}{l}\text { Proj/ } \\
\text { Ac }\end{array}$ & $\begin{array}{l}\text { Proj/ } \\
\text { Ac }\end{array}$ & $\begin{array}{l}\text { Proj/ } \\
\text { Ac }\end{array}$ & $\begin{array}{l}\text { Proj/ } \\
\text { Ac }\end{array}$ & $\begin{array}{l}\text { Proj/ } \\
\text { Ac }\end{array}$ & $\begin{array}{l}\text { Proj/ } \\
\text { Ac }\end{array}$ & $\begin{array}{l}\text { Proj/ } \\
\text { Ac }\end{array}$ & $\begin{array}{l}\text { Proj/ } \\
\text { Ac }\end{array}$ & $\begin{array}{l}\text { Proj/ } \\
\text { Ac }\end{array}$ & Actual \\
\hline 21000 & Income Taxes & 200 & 10 & 10 & 10 & 10 & 10 & 30 & 10 & 10 & 10 & 10 & 30 & 50 & 200 \\
\hline 22000 & Social Contributions & 60 & 5 & 5 & 5 & 5 & 5 & 5 & 5 & 5 & 5 & 5 & 5 & 5 & 60 \\
\hline 24000 & Property Income & 20 & 0 & 0 & 5 & 0 & 0 & 5 & 0 & 0 & 5 & 0 & 0 & 5 & 20 \\
\hline 25000 & Sale of Goods \& Services & 30 & 2 & 2 & 3 & 2 & 3 & 2 & 3 & 3 & 3 & 3 & 2 & 2 & 30 \\
\hline 26000 & Nontax revenues & 50 & 0 & 0 & 0 & 0 & 0 & 20 & 0 & 0 & 0 & 0 & 0 & 30 & 50 \\
\hline 27000 & $\begin{array}{l}\text { Other Revenue (e.g., from } \\
\text { privatization) }\end{array}$ & 20 & 2 & 1 & 2 & 3 & 2 & 1 & 2 & 1 & 2 & 1 & 2 & 1 & 20 \\
\hline 28000 & Grants & 40 & 0 & 0 & 10 & 0 & 0 & 10 & 0 & 0 & 0 & 10 & 0 & 10 & 40 \\
\hline \multirow[t]{2}{*}{29000} & Loans disbursements & 80 & 0 & 0 & 20 & 0 & 0 & 0 & 20 & 0 & 0 & 20 & 0 & 20 & 80 \\
\hline & TOTAL CASH INFLOW & 500 & 19 & 18 & 55 & 20 & 20 & 73 & 40 & 19 & 25 & 49 & 39 & 123 & 500 \\
\hline 11000 & Salaries & 186 & 15 & 15 & 15 & 15 & 15 & 15 & 16 & 16 & 16 & 16 & 16 & 16 & 186 \\
\hline 12000 & Operating Costs & 60 & 4 & 4 & 4 & 5 & 5 & 5 & 6 & 6 & 6 & 5 & 5 & 5 & 60 \\
\hline 13000 & Interest payments (dom. \& ext.) & 30 & 0 & 0 & 0 & 10 & 0 & 0 & 10 & 0 & 0 & 0 & 0 & 10 & 30 \\
\hline 14000 & Capital Expenditure & 70 & 5 & 5 & 12 & 5 & 12 & 12 & 2 & 7 & 5 & 5 & 5 & 5 & 80 \\
\hline 16000 & Grants, Contributions \& Subsidies & 60 & 5 & 5 & 5 & 5 & 5 & 5 & 5 & 5 & 5 & 5 & 5 & 5 & 60 \\
\hline \multirow[t]{3}{*}{18000} & Loan Repayments & 94 & 0 & 0 & 20 & 0 & 0 & 20 & 0 & 0 & 20 & 0 & 0 & 24 & 84 \\
\hline & TOTAL CASH OUTFLOW & 500 & 29 & 29 & 56 & 40 & 37 & 57 & 39 & 34 & 52 & 31 & 31 & 65 & 500 \\
\hline & NET CASH FLOW & 0 & -10 & -11 & -1 & -20 & -17 & 16 & 1 & -15 & -27 & 18 & 8 & 58 & 0 \\
\hline
\end{tabular}

Projected Treasury Balance

\begin{tabular}{|c|c|c|c|c|c|c|c|c|c|c|c|c|c|}
\hline Opening Balance & 20 & 10 & -1 & -2 & -22 & -39 & -23 & -22 & -37 & -64 & -46 & -38 & 20 \\
\hline Net Cash Flow & -10 & -11 & -1 & -20 & -17 & 16 & 1 & -15 & -27 & 18 & 8 & 58 & 0 \\
\hline Closing Balance & 10 & -1 & -2 & -22 & -39 & -23 & -22 & -37 & -64 & -46 & -38 & 20 & 20 \\
\hline
\end{tabular}




\section{Cash Management Challenges in Developing and Middle- Income Countries}

Establishing effective cash management is challenging in many middle- and low-income countries. One important constraint is the absence of modern banking systems, which offer possibilities for treasuries to reduce delays in revenue transmittals and expenditure payments. This, and other limitations, are outlined below:

- The banking system is underdeveloped or underutilized. In order to make electronic payments, treasuries have to await progress in putting in place countrywide computerized networks within and between commercial banks, the central bank, and the treasury/MoF. Cash managers need to be aware of modernization efforts by commercial banks, and prepare themselves to enter new contractual arrangements with banks for providing retail banking services to the treasury. Although the central bank should always be used as custodian for the main operational account of the TSA, transit accounts in the branches of commercial banks, chosen by competitive bidding, offer the best possibilities for receiving taxpayers' revenues electronically and for making disbursements to government suppliers (again electronically), especially for transactions outside the capital city where the treasury and the central bank are located.

- Payments are made in banknotes. In some LICs, treasuries still handle physical cashespecially outside capital cities_-for both revenue collection and making payments, including civil servants' salaries. Cash that is kept in vaults is not remunerated and not centralized in the TSA; and, hence, this practice is contrary to the good cash management principles of pooling liquidity and maximizing returns on temporary cash surpluses.

- Multiple government bank accounts exist. The MoF may not be fully in control of all government bank accounts: other accounts may have been opened by an authority outside the MoF. Whereas the main treasury account is held at the central bank, other government bank accounts (not under treasury oversight) may proliferate in commercial banks. The MoF may lack authority to close accounts outside its control, for example, those of the presidency, ministry of defense, etc. Besides multiple accounts by government agencies, donors, and external creditors often insist on opening special accounts (as well as other complex donorspecified procedures) for payments for donor-financed development projects. Such practices by donors or creditors constrain the comprehensiveness of the TSA.

- Daily balances in all government accounts are unknown. If the MoF is unaware of the end-of-day balances in all government bank accounts or is unable to access these balances for cash management purposes, efficient cash management is impossible. Since government cash in the banking system is typically unremunerated or low yielding, there is a considerable opportunity cost. ${ }^{16}$

\footnotetext{
${ }_{16}$ Most of the funds tend to be held on a demand deposit basis, which typically offers very low or no return. If the funds are consolidated in a TSA the cash manager can decide as to whether term deposits can be used for at least a portion of the balances, which should enhance the yield.
} 
- Unnecessary borrowing occurs. Instead of using idle balances, the government issues treasury bills or other forms of debt to finance its cash spending. Commercial banks benefit from this practice. First, they use the idle government deposits to purchase treasury bills. Second, whereas they do not remunerate government deposits, they receive interest from government on the treasury bills they purchase.

- Cash flow forecasts are not prepared. Developing countries may not prepare rolling shortterm cash plans. This may reflect institutional or technical difficulties, including the lack of an effective cash management unit with adequate capacity to obtain all of the relevant data needed for developing cash plans.

- "Cash management" is mainly about expenditure control. Modern cash management is not concerned with controlling expenditure authorizations so that the timing of cash disbursements matches the timing of cash receipts. In many countries, in-year expenditure authorization and control is often delegated to spending ministries, which are responsible for notifying central cash managers of their cash plans, particularly the precise timing of large-value disbursements. Advanced countries do not rely on expenditure controls as a cash management tool, since such controls can be disruptive for spending ministries, add to procurement costs, and impose burdens on private sector suppliers. In contrast, in many LICs, "cash management" is not distinguished from cash rationing —enforced by cuts in budget allocations. ${ }^{17}$ For example, in some anglophone African countries, "cash budgeting" systems release the authority to incur expenditure only when adequate cash is available. In francophone countries, "cash management" is often viewed as limiting expenditure commitments to below that approved in the annual budget law, consistent with cash expected to be available. In both regions, the trimming of spending authorizations concerns "nonpriority" spending. However, the criteria for cuts are not always clear and, at times, the MoF's rules are circumvented. ${ }^{18}$ Although it may occasionally be necessary for the MoF to delay or cancel budget authority-especially if budget revenue projections are too optimistic — such procedures are not an intrinsic component of modern cash management. Nonetheless, in all countries, it is important that budget managers/ controllers know the timing and size of cash needs that result from approved spending commitments, and communicate these to the MoF's cash management unit.

- Expenditure arrears have arisen. Payment arrears arise for a variety of reasons, including poor budget preparation (unrealistic projections), non-compliance with budget execution procedures, and inadequate cash management. Nonpayment by government to suppliers is a costly form of government borrowing. First, the credibility of government as a payer is undermined. Second, suppliers react by raising prices higher than they would be otherwise, to

\footnotetext{
17 In former Soviet countries in the 1990s, expenditure "sequestering" was commonplace. It was a direct consequence of parliament adopting a budget with revenues and expenditures much higher than the parallel "real" budget implemented by the executive.

18 In several francophone African countries, the use of treasury advances for "urgent" unforeseen spending is abused. Successive advances are made for nonbudgeted spending and advances are not regularized according to the treasury's regulations. This drains cash available for regular budget spending, which is executed by standard procedures, notably payment after internal controls and delivery of goods and services.
} 
compensate for the anticipated late payment by government. Third, suppliers may underdeliver quantities or skimp on the quality of goods and services, in complicity with government officials. Fourth, in some government contracts, penalties for late payment are higher than commercial banks' borrowing rates. When payment arrears are addressed in a one-off clean-up exercise, the stock of outstanding government debt, and debt servicing, increases sharply, with implications for cash management.

- IT systems are underdeveloped. Computerized IMISs, which provide rich databases, are often lacking in LICs. Although progress is being made in introducing IFMISs in a number of countries, the quality of data available for making projections is often substandard, especially for the provision and timeliness of the high-frequency data needed for making reliable projections.

- Lack of human capacity. In many LICs, the required skilled staff are often not available, because of low civil service salaries, incomplete understandings of the importance of cash planning, or inadequate management attention to eliminate the "leakages" associated with poor cash management.

Each of the above issues or problems need to be part of a cash management reform plan.

\section{Sequencing of Cash Management Reforms}

This section outlines four stages involved in moving from primitive cash management to active daily cash management. ${ }^{19}$ The stages are shown for illustrative purposes-they are not mutually exclusive. In countries where there is no effective cash management or where cash "management" is dominated by expenditure control systems, it will take many years to move from the first two phases-meeting prerequisites and introducing basic cash planning - to the final stage of active daily cash management.

The speed at which cash management can be improved depends on: (1) the starting point, especially the extent to which basic conditions for effective cash management are in place; (2) the willingness of national authorities to reform cash management practices, to confront resistance to full treasury oversight of all government bank accounts, and to enhance the transparency of government operations at transaction level; (3) the infrastructure available for rapid transfer of funds by electronic means; (4) the degree to which financial markets have developed, including end-of-day bank account "sweeping" and financial market instruments available for daily cash management; and (5) human capacity and organizational arrangements.

\section{Phase 1: Addressing fundamentals}

The six fundamental features of cash management shown in Box 1 are preconditions for developing effective modern cash management. Given that relatively long time periods are

19 This section has benefited from the cash management reform strategy laid out in Williams (2004). 
required to complete some of individual steps, one has to be realistic when establishing plans to complete the steps listed below. For example, even in middle-income countries, it may take a decade to establish an operational TSA. The steps listed below would need to be sequenced, as part of the overall cash management reform.

- Establishing a cash management unit (CMU). It is desirable to establish a technical cash management unit in the MoF. This would normally be located in the Treasury Department, although the Budget Department would be involved also (especially if it is involved in budget execution).

- Establishing a policy-making cash management body. For cash management policy decisionmaking, a high-level committee is also required. In cash rationing environments, the committee would establish cash ceilings for ministries. In such situations, there is a temptation for these committees to become cash triage committees, deciding what bills get paid, in what order. Clear and transparent rules for ordering payments should be established, in order to minimize corruption. In more sophisticated environments, the policy-level committee would decide on short-term borrowing, placement of temporary surpluses, and cash balance remuneration policies, in collaboration with the central bank.

- Highlighting the importance of effective cash management. In some developing countries, the financial costs of maintaining idle balances in multiple government bank accounts are unknown. There may also be a reluctance to reveal the extent to which government cash is hidden in domestic or foreign-currency bank accounts, outside the control of the national Treasury. Identifying and publicizing the costs of ineffective cash management enhances the awareness of good cash management practices. The opportunity cost (interest foregone) of maintaining idle government balances in cash or in multiple government bank accountsincluding float in revenue and expenditure accounts—should be calculated. Less tangible costs, including the reputation costs of the government not paying on time (accumulation of payment arrears), should also be made public.

- Ensuring realistic annual budget projections. Although optimistic revenue projections or the underestimation of budget expenditures are not cash management problems per se, unrealistic annual budget projections engenders cash management problems, especially in countries where borrowing is not an option. When annual budget projections and short-term cash plans are not well integrated, it is helpful if annual domestic revenue projections are conservative, the timing of revenue grant inflows (including grants) is known with some precision, and the costing of current and capital expenditures in annual budget projections is as accurate as possible.

- Establishing an operational TSA. The pooling of all revenues in one operational bank account at the central bank and the making of payments from the same account can take considerable time to implement. As a first step, a census of all government bank accounts is helpful, leading to the closing of unjustified accounts. This would be followed by bringing all important government bank accounts under treasury control and beginning to implement the zero end-day balance principle for accounts that remain open. The maintenance of small amounts in bank accounts outside the TSA, for petty cash needs of spending ministries, would 
be acceptable as a temporary measure and could reduce resistance in moving towards a fullfledged TSA. Similarly, in remote regions of some LICs, where there are no commercial banks, physical cash may need to be maintained in vaults, and used for payments in cash.

- Avoiding use of physical cash. As banking systems develop, the use of cash should progressively be phased out as a payment instrument, both by the government and by taxpayers. When cash is transferred into vaults, there is a risk that funds will be siphoned off for other uses.

- Limiting cash advances. In some LICs, the release of cash advances to line ministries can result in cash shortages for certain budgeted expenditures. To avoid such problems, treasury advances should be limited in size and by type of expenditure. Moreover, line ministries should be made accountable, by requiring them to justify the use of treasury advances prior to their replenishment with new advances.

- Improving government accounting. Without timely, comprehensive and high-frequency data for financial inflows and outflows, it is difficult to prepare sound short-term projections and cash plans. Addressing the major weaknesses in government accounting systems provides a firmer basis for early steps towards preparing well-grounded short-term cash projections. This includes improving the quality of accounting data, especially by ensuring that accounting and banking records are fully reconciled on a regular basis.

- Modifying the legal framework. To strengthen the MoF's authority to rationalize government banking arrangements and establish a TSA, amendments in laws and regulations may be needed. If the application of existing laws and regulations is lax, decision-makers should implement measures to enhance enforcement.

\section{Phase 2: Preparing cash plans and developing cash management skills}

- Preparing short-term projections of cash flows. The CMU would be responsible for preparing short-term projections of cash inflows and outflows (initially on spreadsheets), analyzing recent projection performance, updating the database, and revising short-term projections. One area of focus should be on ensuring that the timing and amounts of large inflows or outflows are as accurate as possible.

- Establishing information-sharing arrangements. A network at technical level should be established, with representatives from the revenue-collection agencies, MoF departments (especially the budget, debt, and treasury departments), major spending ministries and agencies, and the central bank, to provide inputs for projections of short-term cash flows.

- Ensuring information exchanges for cash projections takes place. To prepare short-term projections of cash flows, it is necessary for cash managers in the MoF to receive information on past and projected inflows and outflows. The CMU should distinguish flows that occur regularly (e.g., on the same day of a given month) and are always relatively easy to project 
(e.g., consumption of electricity, gas, water in government ministries) from those that are less predictable, such as payments for certain large projects or spending for legal claims settlements against the State. When there are large inflows (e.g., a large privatization receipt ${ }^{20}$ ), cash managers should be consulted so that a day for transferring the funds to the TSA is chosen when there are outflows rather than inflows.

- Preparing cash plans. Monthly, bi-monthly, or weekly cash plans should be prepared in the first instance. Frequencies should be progressively shortened, with the ultimate objective of preparing daily cash plans (see below).

- Developing cash projection skills. The preparation of cash plans is a technical exercise that requires trained staff to project, monitor, analyze and update projections. The CMU needs to be staffed by people with appropriate skills.

\section{Phase 3: Going beyond prerequisites and basic cash planning}

- Shortening revenue transmittal delays. If there are delays in transmitting taxes, nontax revenues, grants, and proceeds from loans or securities into the TSA, steps should be taken to shorten, and eventually eliminate, them. Close collaboration between the revenue-collecting agencies and the treasury is required. ${ }^{21}$

- Coping with seasonality and "lumpiness" in cash inflows. Cash management is facilitated when revenues and expenditures are relatively even; although there is inherent seasonality in some revenues or expenditures, for example, school textbooks are ordered and paid for once a year. Nonetheless, there may be scope, in some cases, for limiting seasonality. On the revenue side, for example, taxpayers could be asked to pay more frequently, monthly instead of quarterly or annually. A review of tax regulations from a cash management perspective would be a useful one-off exercise. For aid-dependent countries, more regular and predictable cash disbursement of budget support by donors is most helpful for cash planners. On the expenditure side, in low- and middle-income countries there may be a need to review budget execution procedures and carry-over rules, so as to avoid the backloading of spending until the final few months of the fiscal year, i.e., reverse the "spend it or lose it" mentality.

- Assessing the impact on cash projections of expenditure commitments in the pipeline. The decision to commit to spend budget allocations is usually made by budget managers in spending ministries and agencies. Budget managers with responsibility for large expenditures should be required to submit regularly to the treasury the time profile of expected cash disbursements of outstanding spending commitments, to enable the treasury to include these when updating cash plans. Budget managers have to be aware of possible delays in government

\footnotetext{
${ }^{20}$ The amount of the sale of a government asset, if by auction, may be uncertain, but the approximate amount and the timing is known.

${ }^{21}$ In the United States, special Treasury Tax and Loan (TT\&L) accounts are used for keeping Treasury funds invested in commercial banks until needed. This may give the appearance that tax receipts are not leaving the commercial banking system. However, deposits in TT\&L accounts are fully collateralized, pay a market interest rate, and are withdrawn when needed. These arrangements are akin to relending surplus federal government deposits, although they do not actually transit through the TSA held at the Federal Reserve Bank in New York.
} 
procurement processes. If necessary, government contracting procedures may need to be reviewed in order to reduce delays in procurement, which would result in an increase in the accuracy of the cash implications of government procurement contracts in the pipeline.

- Processing expenditure approvals and payments efficiently. In countries with complex expenditure approval processes, any duplication of the responsibilities of multiple players involved in intermediate handling should be eliminated. For example, in some Latin American countries, the external audit office approve each spending request (and, in some cases, even sign the checks). These pre-audits duplicate checking done by government ministries, which may need to develop their internal audit capacity.

- Computerizing expenditure processes. Increased reliance on computerized processing and electronic payment can shorten lags between spending commitments and payments, and reduces the necessity for expenditure commitment control to be used as an instrument for effective cash management. ${ }^{22}$

- Maintaining a minimum cash balances. Unremunerated balances should be minimized. However, a minimal cash balance is needed when "rough-tuning" cash management is practiced. The size of the threshold for the cash balance is higher than in situations where cash is managed actively on a daily basis (see below).

- Remunerating idle cash balances. It is good practice for central banks to remunerate government balances over a minimum threshold (IMF, 1999). Negotiations with the central bank are needed to rectify situations where the treasury does not receive adequate remuneration. ${ }^{23}$ As a question of principle, remuneration of government deposits should be linked with market interest rates.

- Extending TSA coverage. The treasury should obtain access to all government bank accounts, so as to only borrow when it is essential. Any unutilized non-TSA (extrabudgetary) bank account balances should be used for cash management purposes unless there are legal constraints preventing this. If necessary, arrangements can be put in place for "lending" the cash to the treasury. ${ }^{24}$ In developing countries, donors should allow grant or loan disbursements into special accounts to be used for cash management in recipient countries. ${ }^{25}$

- Coordinating cash and debt management. As the government debt management function develops-including issuance of treasury bills on the domestic market and bond issues on international markets—close coordination is needed between government cash managers

\footnotetext{
22 See Guidance Note No. 4 on expenditure commitment control, available on http://blog-pfm.imf.org.

23 Negotiations can sometimes be difficult. A central bank is concerned about its balance sheet and its profit and loss account. For example, a central bank may be obliged to hold underperforming assets at government behest, such as special bonds issued to restructure the banking system. Central banks may also argue that "since we transfer our profits to the government at end-year, it does not matter." However, central bank profits are never transferred in total (general and special reserves are retained) and the timing of the transfer is infrequent.

${ }^{24}$ For example in Brazil, where the law gives some agencies autonomy in managing their own resources, as an incentive for them to transfer funds to the TSA, their deposits (when transferred) are remunerated at a rate similar to that paid by the central bank on TSA deposits.

25 This would promote procedural harmonization, as envisaged in the Paris Declaration on Aid Effectiveness, see http://www.oecd.org/searchResult/0,3400,en_2649_201185_1_1_1_1_1,00.html
} 
and debt managers, so as to establish a bond issuance program that takes account of the cash profile, to avoid unnecessary debt issuances, and to ensure that interaction with the money and bond markets is handled consistently.

- Using banking facilities. Electronic payment methods are being introduced in many countries. After phasing out transactions in physical cash, the next step is to phase out the use of checks, by replacing paper-based payments with direct electronic payments. This could begin, for example, by requiring all high-level civil servants to open commercial bank accounts, into which monthly salaries are directly transferred. Enhanced use of banks' internal electronic payment networks (e.g., RTGS) eliminates payment delays and the need to maintain overnight balances in government bank accounts outside the TSA's main operational account at the central bank.

- Formalizing relations with banks for treasury services. Commercial banks should be contracted—on a competitive bidding basis wherever possible 26 -for the provision of transactional banking services to the treasury. Using commercial banks is more efficient than establishing a network of treasury branch offices ${ }^{27}$ since supplying transactions services is a core expertise of banks and economies of scale can be reaped. The central bank usually only has a limited number of branch offices; it is not the central bank's role to provide retail banking services to government.

- Clarifying the relationship between the treasury and the central bank. To improve the transparency of the relationship between the (independent) central bank and the treasury, the arrangements for consultation between the government cash manager and the central bank can be covered by a memorandum of understanding. It is also good practice to draw up a "service level agreement" (SLA), which elaborates on the treasury services provided by the central bank. Issues covered by the SLA might include: (1) the notice that both sides would give of any impending change in the operational timetable, for example, for auctions or announcements; (2) the turnaround times by the central bank in handling government transactions; (3) the sharing of information flows in either direction and account balances; (4) the remuneration of accounts, the fees paid for the services, and the basis of both calculations; (5) the limits and conditions on borrowing from the central bank,28 and, (6) the handling of any business continuity problems.

\footnotetext{
${ }^{26}$ Where the banking system is oligopolistic and competition is limited, the treasury could establish a fixed rule to choose banks that would like to provide treasury banking services to the government, for example, it could propose a standard remuneration based on estimated costs per transaction.

27 In countries where a network of treasury field offices has already been established (e.g., francophone countries), in the first instance it is appropriate to continue to use treasury network "banking" services.

28 Some countries (e.g., members of the EU and the West and Central African Monetary Unions) prohibit the government from borrowing the central bank. Although several Latin American have also changed laws to prohibit borrowing from the central bank, a few Latin American countries still allow such borrowing.
} 


\section{Phase 4: Introducing active daily cash management}

As government cash management operations advance, there is need to go beyond the intermediate phase of "rough tuning"- - using issuances of short-term treasury bills to smooth the peaks and troughs in cash balances-and increase the focus on daily management of available cash. The following refinements can be made.

- Becoming more active in daily management of cash balances. As the instruments for "finetuning" become available and the updating of short-term projections becomes more frequent, an operating target for the daily balance in the TSA should be established. Any temporary surpluses would be invested in financial markets. Even when countries do not have an explicit daily operating target, for example, Australia, the cash management office aims to reduce the daily fluctuations in the TSA balance.

- Introducing daily bank account "sweeping" arrangements. In countries where the cash management function is delegated, each budget entity is authorized to have separate transactional bank accounts, from which they can make payments. However, all balances in these accounts are swept up into the main TSA, at least once a day. ${ }^{29}$ This is possible when electronic banking systems allow daily clearing and settlement of government bank accounts.

- Ensuring the security of short-term placements by the treasury. The use of collateralized deposits or instruments, such as reverse repos (which are fully-collateralized), eliminates default risk. The requirement for full collateral for temporary placements is especially important in countries with a history of fragile banks. In countries with sound banking systems, a small portion of treasury placements are sometimes made on an uncollateralized basis, although credit risk considerations are taken into account in any placement decisions. ${ }^{30}$

- Refining cash flow projections. As the focus turns towards daily projections of inflows and outflows, the accuracy of projections needs to be enhanced, including for the exact timing of large-value transactions. There needs to be a well-qualified team able to refine the forecasts intensively (especially for the immediate days ahead), in line with new information on actual flows. Capacity to refine within-the-day projections is also needed. ${ }^{31}$ Daily projections should extend out for at least two to three months. ${ }^{32}$ Refining projections requires enhancements in the feedback from revenue-collection agencies for revenue projections, ministries and agencies on their cash needs, and with the central bank for consultations on proposed market interventions

\footnotetext{
29 Whereas the "sweep" in several advanced countries is once a day, Sweden sweeps the bank accounts of its 240 or so spending agencies three times per day. With such intense daily cash management, Sweden is able to maintain a zero end-day balance in its TSA at Sweden's Central Bank (see Swedish National Debt Office, 2006), i.e., its target cash balance at the end of each day is zero (see the countries and balances listed in footnote 11).

${ }^{30}$ Even in developed countries imprudent decisions can be made. See, for example, the case of municipalities in the U.S. state of Florida, reported on http://blog-pfm.imf.org/pfmblog/2008/01/cash-management.html.

${ }^{31}$ In the United Kingdom, by 2 p.m. the government has received 60 percent of the over-the-counter tax payments it is likely to collect that day (see Williams, 2003). This information is used in forecasts.

32 Advanced countries usually have longer time periods for which daily projections are made, in some case for many months, for example, 12 months for France, 9 months for the United States.
} 
by the treasury. Incentives can be provided to encourage spending agencies to enhance the accuracy of projections of their cash needs (see footnote 13).

- Strengthening coordination. Daily cash management requires very frequent coordination between the cash manager, the government debt manager, and the monetary authorities. Coordination is especially important when government cash managers become active in financial markets, since the MoF's actions affect commercial bank liquidity, which the central bank aims to control through monetary policy instruments. In advancing to more sophisticated cash management systems, the distinct responsibilities of cash managers, public debt managers, and the monetary authorities may have to be delineated more clearly, in updated memoranda of understandings. 


\section{References}

Agence France Trésor (AFT), 2006, Annual Report, 2005-06, available via Internet: http://www.aft.gouv.fr.

2007, Cash Management in 10 questions, available via Internet: http://www.aft.gouv.fr/aft_ en_21/cash_management_56/in_10_481/index.html\#957.

International Monetary Fund, 1999, Location of Government Deposits: Implications for Monetary Operations, Monetary and Exchange Affairs Department Operational Paper, MAE OP/99/2, July (Washington).

International Monetary Fund and World Bank, 2001, Developing Government Bond Markets: A Handbook (Washington).

International Monetary Fund and World Bank, 2003, Guidelines for Public Debt Management (Washington).

IMF, 2007, "Northern Star: Canada's Path to Economic Prosperity", IMF Occasional Paper 258 (Washington).

Rascoe, Mary, 2007, "Managing the Nation's Money," presentation made at the sixteenth Annual Government Financial Management Conference, Financial Management Service, U.S. Department of the Treasury, Washington, D.C.

Storkey, Ian, 2003, Government Cash and Treasury Management Reform, Asian Development Bank, Governance Brief, Issue 7-2003, www.asiandevbank.org/Documents/Periodicals/GB/ GovernanceBrief07.pdf.

Swedish National Debt Office, 2006, Concentrated Activities Lead to Efficient Financial Management, Forecast and Analysis 2006:2, https://www.riksgalden.se/default_EN___1559.aspx.

Williams, Mike, 2003, Forecasting Government Cash Flows in the United Kingdom. Available via Internet: http://www.mj-w.net/cac_gov_cash.html.

Williams, Mike, 2004, Government Cash Management: Good and Bad Practice. Available via Internet: http://www.mj-w.net/cac_gov_cash.html.

Wheeler, Graeme, 2004, Sound Practice in Government Debt Management, (Washington: World Bank). 